Clinical Science

\title{
PREVALENCE OF CAROTID ARTERY DISEASE IN PATIENTS WITH METABOLIC SYNDROME
}

\author{
Tatjana Deleva-Stoshevska ${ }^{1}$ \\ City General Hospital "8th September", Skopje, Republic of North Macedonia
} Citation: Deleva-Stoshevska T. Prevalence of ca-
rotid artery disease in patients with metabolic rotid artery disease in patients with metabolic
syndrome Arch Pub Health 2020; 12 (3). https://doi org/10.3889/aph.2020.5416

Key words: carotid artery disease, cerebrovascular insult, transient ischemic attack, metabolic syninsult,

*Correspondence: Tatjana Deleva-Stoshevska. City General Hospital "8th September", Skopje, Republic of North Macedonia E-mail: deleva_tatjana@ yahoo.com

Received: 21-Apr-2020; Revised: 17-Jun-2020; Accepted: 5-Jul-2020; Published: 15-Dec-2020

Copyright: ${ }^{-}$2020. Tatjana Deleva-Stoshevska. This is an open-access article distributed under the terms of the Creative Commons Attribution License, which permits unrestricted use, distribution, and reproduction in any medium, provided the original author(s) and source are credited.

Competing Interests: The author have declared that no competing interests

\section{Abstract}

There is a growing body of scientific evidence on the impact of metabolic syndrome (MetS) on the progression of atherosclerosis, imposing the need for research of the association of MetS with carotid artery disease (CAD) as a significant risk factor for cerebrovascular insult (CVI) and transient ischemic attack (TIA). The aim of the study was to determine the prevalence of CAD as a risk factor for CVI and TIA in subjects with MetS. Material and methods: A cross-sectional study was performed including a total of 118 subjects, 65 men, 53 women, with MetS according to NCEP ATP III criteria that were analyzed clinically, biochemically and ultrasonographically in the City General Hospital „8th September“ - Skopje in the period from January 2017 to January 2018. Waist circumference, blood pressure, glycemia, triglycerides, and HDL cholesterol were determined according to standard routine protocols. The evaluation of the extracranial carotid trunk was done with a Color Doppler Duplex sonography with a linear probe of 7.5MHz. CAD assessment was performed using Ultrasound Consensus Criteria for Carotid Stenosis. An objective neurological assessment of the existence of CVI and TIA was performed by a standard protocol for neurological examination and brain CT results from medical history were reviewed. Results: The prevalence of CAD in this study was 77 subjects (65.25\%), of which 35 subjects (29.66\%) had symptomatic CAD, 17 subjects (48.57\%) had CVI, 18 subjects (51.43\%) had TIA. Regarding the degree of carotid artery stenosis (CAS) in the total number of subjects with MetS and CAD, no subjects with normal findings were registered, 16 subjects had stenosis $<50 \%$, 29 subjects had stenosis 50-69\%, 23 subjects had stenosis 70-99\%, while 9 subjects had occlusion. Conclusion: The results obtained in this study have shown that asymptomatic $\mathrm{CAD}$ is dominant in patients with MetS, which further imposed the need for timely extracranial ultrasonographic evaluation of the carotid trunk. This would achieve both effective prevention and adequate treatment of CVI and TIA, thereby reducing morbidity and mortality from cerebrovascular events which has a great health and socioeconomic significance.

\section{КЛИНИЧКИ КАРАКТЕРИСТИКИ НА КОВИД-19 КАЈ ДЕЦАТА ВО ИНСТИТУТОТ ЗА БЕЛОДРОБНИ БОЛЕСТИ КАЈ ДЕЦАТА-СКОПЈЕ}

\author{
Татјана Делева Стошевска ${ }^{1}$ \\ Граяска ойшӣа болница „8-ми Сейш̄ември“, Скойје, Рейублика Северна Макеgонија
}

Цитирање: Делева Стошевска Т. Преваленција на каротидна артериска болест кај пациција на каротидна артериска болест кај паци2020;12(3). https://doi.org/10.3889/aph.2020.5416

Клучни зборови: каротидна артериска болест, цереброваскуларен инсулт, транзиторна исхемична атака, метаболички синдром.

*Кореспонденција: Татјана Делева Стошев ска, Градска општа болница „8-ми Септември“ Скопје, Република Северна Македонија. E-mail: deleva_tatjana@yahoo.com

Примено: 21-апр-2020; Ревидирано: 17-јун-2020; Прифатено: 5-јул-2020; Објавено: 15-дек-2020

Печатарски права: ${ }^{\circledR 2} 2020$ Татјана Делева Стошевска. Оваа статија е со отворен пристап дистрибуирана под условите на нелокализирана лиценца, која овозможува неограничена ипотреба, дистрибуција и репродукција на било кој медиум, доколку се цитираат ориги налниот(ите) автор(и) и изворот.

Конкурентски интереси: Авторот изјавува дека нема конкурентски интереси.

\section{Извадок}

Расте бројот на научни докази за влијанието на метаболичкиот синдром (MetS) врз прогресијата на атеросклерозата, што ја наметнува потребата за истражувања на поврзаноста на MetS co каротидна артериска болест (CAD) како значаен ризик-фактор за цереброваскуларен инсулт (CVI) и транзиторна исхемична атака (TIA). Целта на овој труд беше да се утврди преваленцијата на CAD како ризик-фактор за CVI и TIA кај испитаниците co MetS. Материјал и методи: Ова е студија на пресек во која беа вклучени 118 испитаници, 65 мажи, 53 жени, co MetS согласно NCEP ATP III критериумите. Пациентите беа анализирани клинички, биохемиски и ултрасонографски во ГОБ „8-ми Септември“ - Скопје во периодот од јануари 2017 до јануари 2018 година. Согласно стандардните рутински протоколи беа одредувани вредностите за обемот на половината, крвниот притисок, гликемијата, триглицеридите и HDL холестеролот. Евалуацијата на екстракранијалното каротидно стебло беше правена co Color Doppler Duplex сонографија со линеарна сонда со фреквенција од 7,5 MHz. Проценката на CAD беше направена со користење на ултразвучни консензус критериуми за каротидна стеноза. Објективната невролошка проценка за постоење на CVI и TIA се вршеше со невролошки преглед по стандарден протокол и со резултатите од КТМ од медицинската историја. Резултати: Вкупната преваленција на CAD кај сите испитаниците co MetS во оваа студија беше 77 испитаници (65,25\%); од нив симптоматска CAD имаа 35 испитаници (29,66\%) од кои 17 испитаници (48,57\%) беа co CVI, а 18 испитаници (51,43\%) беа со TIA. Во однос на степенот на каротидна артериска стеноза (CAS) кај вкупниот број испитаници со MetS и CAD не беа регистрирани испитаници со нормален наод; 16 испитаници имаа стеноза < 50\% , 29 испитаници имаа стеноза 50-69\%, 23 испитаници имаа стеноза 70-99\% , додека, пак, оклузија имаа 9 испитаници. Заклучок: Резултатите од оваа студија покажаа доминација на асимптоматска CAD кај испитаниците co MetS, со што дополнително се наметнува потребата за навремена екстракранијална ултрасонографска евалуација на каротидното стебло. Со тоа би се постигнала ефикасна превенција и адекватен третман на CVI и TIA, намалување на морбидитетот и морталитетот од цереброваскуларни настани што има големо здравствено и социоекономско значење. 


\section{Introduction}

The influence of the metabolic syndrome on the progression of atherosclerosis has been confirmed in the results of numerous studies, which have also shown a correlation between carotid atherosclerosis and generalized atherosclerosis. Because of this, subjects with MetS are at an increased risk of developing carotid artery disease, cardio and cerebrovascular disease, diabetes mellitus ${ }^{1}$. The underlying pathophysiology of MetS is obesity and insulin resistance, but it is more complicated and involves a number of other factors, including genetic and environmental factors ${ }^{2}$. Carotid artery disease (CAD) involves changes in the arterial wall that cause IMT to thicken, narrow or completely obstruct the carotid artery lumen. Atherosclerosis is the most common cause of CAD. Other non-atherosclerotic causes are rare and include carotid dissection, fibromuscular dysplasia, arteritis (Takayasu), radiation, glomerular tumors on bifurcation, and trauma ${ }^{3}$. That is why atherosclerotic extracranial CAD is included in this study. Selection sites for CAD are carotid bifurcation, the ACI ostium, including the posterior outer wall of the carotid sinus and the distal part of common carotid artery. CAD can be asymptomatic and symptomatic. Asymptomatic CAD is without clinical manifestation of brain suffering, whereas symptomatic CAD may manifest clinically as TIA or CVI. CVI is a medical condition in which poor blood flow to the brain results in the death of cells by initiating an ischemic cascade. TIA is a brief episode of neurological dysfunction with vascular cause, with clinical symptoms usually lasting less than an hour and without imaging evidence of infarction ${ }^{4}$. Disorders phenomenology at CVI and TIA depends on which part of the brain is affected by ischemic suffering.

The aim of the study was to determine the prevalence of $\mathrm{CAD}$ as a risk factor for CVI and TIA in subjects with MetS.

\section{Material and methods}

This cross-sectional study comprised a total of 118 subjects with MetS according to NCEP ATP III (National Cholesterol Education Program, Adult Treatment Panel III) criteria, aged $\geq 30$ and $\leq$ 80 years, that were analyzed clinically, biochemically and ultrasonographically in the City General Hospital "8th September" - Skopje in the period from January 2017 to January 2018.

NCEP ATP III criteria - having any of the three or more of the following parameters:

1. Abdominal obesity - increased waist circumference values $\geq 102$ cm (40 in), women $\geq 88 \mathrm{~cm}$ (35 in);

2. Increased triglycerides $\geq 150 \mathrm{mg} /$ $\mathrm{dL}(1.69 \mathrm{mmol} / \mathrm{L})$, or treatment for elevated triglycerides (e.g. fibrates or nicotinic acid);

3. Decreased HDL cholesterol values for men $<40 \mathrm{mg} / \mathrm{dL}(1.03 \mathrm{mmol} / \mathrm{L})$, women $<50 \mathrm{mg} / \mathrm{dL}(1.29 \mathrm{mmol} / \mathrm{L})$, or medication treatment for lower HDL cholesterol levels (e.g. fibrates or nicotinic acid);

4. Elevated blood pressure values: systolic $\geq 130 \mathrm{mmHg}$ and / or diastolic $\geq 85 \mathrm{mmHg}$; or treatment with hypertension medications;

5. Elevated fasting blood glucose values $\geq 100 \mathrm{mg} / \mathrm{dL}(5.6 \mathrm{mmol} / \mathrm{L})$; or treatment with antidiabetic drugs.

Inclusion criteria: people with MetS according to NCEP ATP III criteria, age $\geq 30$ and $\leq 80$ years. Exclusion criteria: individuals without MetS, pregnant women, nursing mothers, age $<30$ and $>80$. All participants were informed about the purpose of the research and an informed consent was obtained prior to the study.

MetS assessment was performed according to NCEP ATP III (National Cholesterol Education Program, Adult Treatment Panel III). Waist circumfer- 
ence was measured at the end of the slow expirium with a soft, elastic band in the upright position of the subject at the midpoint between the upper edge of the iliac bone and the lower edge of the last rib. A mean of two blood pressure measurements with a standard sphygmomanometer was used after a short rest in the sitting position. In the main laboratory of CGH "8th September" - Skopje, venous blood samples were taken after an all-night starvation to assess the following parameters: fasting glycemia, triglycerides and high-density lipoprotein cholesterol (HDL-C). An objective neurological assessment of the existence of CVI and TIA was performed by a standard protocol for neurological examination and brain $\mathrm{CT}$ results from medical history were reviewed. CAD evaluation was performed by an ultrasound scan of the extracranial carotid arteries with an Esaote MyLab тм 70 XVG, with a linear probe with a transmission frequency of $7.5 \mathrm{MHz}$, using B-mode, color and Doppler mode. CAD assessment was performed using Ultrasound Consensus Criteria for $\mathrm{Ca}-$ rotid Stenosis: I. Absence of Stenosis (Normal Finding) - No Plaques, Normal IMT, PSV $<125 \mathrm{~cm} / \mathrm{s}, \mathrm{ACI} / \mathrm{ACC}$ Ratio of PSV $<2$, EDV $<40 \mathrm{~cm} / \mathrm{s} ; 2$. II Stenosis $<50 \%$ : present plaque $<50 \%$, IMT thick,
PSV $<125 \mathrm{~cm} / \mathrm{s}, \mathrm{ACI} / \mathrm{ACC}$ ratio of PSV $<2$, EDV <40 cm/s; III Stenosis <5069\%: IMT thick, visible plaque $>50 \%$, PSV $125-230 \mathrm{~cm} / \mathrm{s}, \mathrm{ACI} / \mathrm{ACC}$ ratio of PSV 2-4, EDV 40-100 cm/s. IV Stenosis $70 \%$ to subocclusive (up to 99\%): visible narrowing $>50 \%, \mathrm{PSV}>230 \mathrm{~cm} / \mathrm{s}$, $\mathrm{ACI} / \mathrm{ACC}$ ratio of $\mathrm{PSV}>4, \mathrm{EDV}>100$ $\mathrm{cm} / \mathrm{s}$; V Subocclusion/near occlusion: significant visible narrowing; nearly occluded artery, PSV may be low or no detectable, ACI/ACC ratio of PSV variable, EDV variable; VI Occlusion: no flow, lumen visible, PSV no flow, undetectable, ACI/ACC ratio of PSV not applicable, EDV not applicable.

The statistical analysis of data was performed with the statistical program SPSS for Windows, 23.0. To compare the groups of subjects, the parameter tests (t-test for independent samples, analysis of variance) were used.

\section{Results}

The overall prevalence of CAD among subjects with MetS in this study was 77 subjects (65.25\%), The overall prevalence of CAD in terms of gender distribution was 36 women (30.51\%) and 41 men (34.75\%) (Figure 1). Gender distribution showed no statistical significance $(\mathrm{p}=0.24)$.

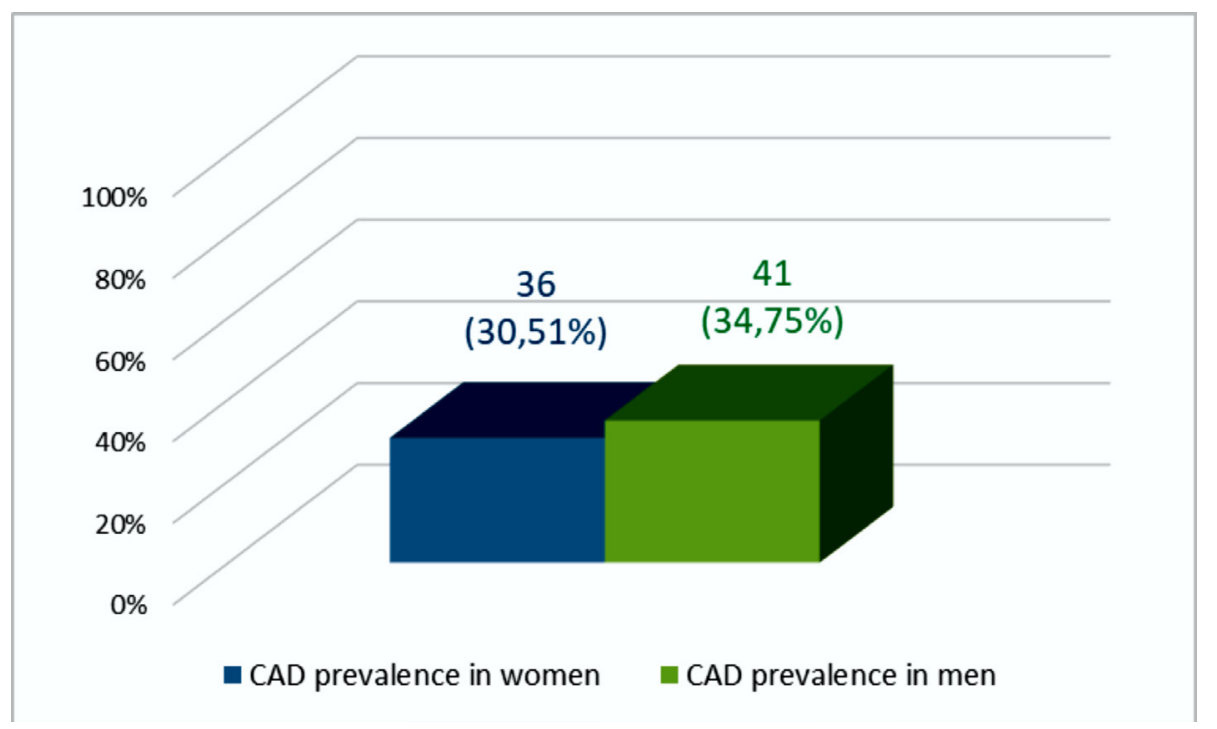

Figure 1. Distribution of CAD by demographics of the study subjects 
Of the total number of subjects, 35 had CVI, 18 subjects (51.43\%) had subjects $(29.66 \%)$ were with symptom- TIA, and the remaining 42 subjects atic CAD of which 17 subjects (48.57\%) (35.59\%) were asymptomatic.

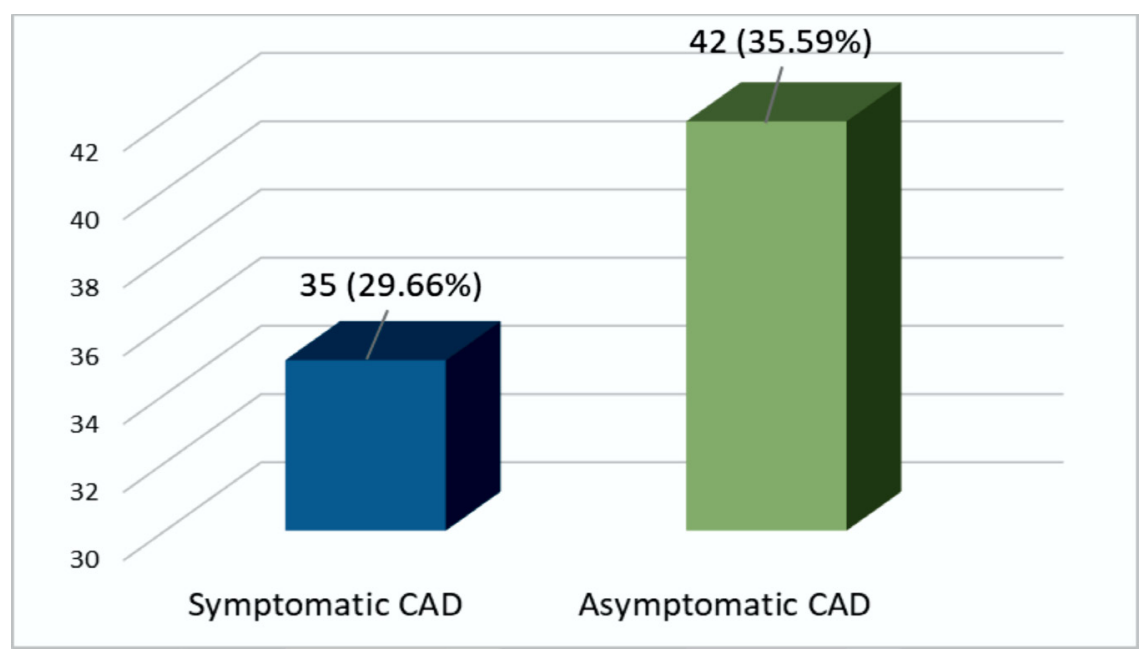

Figure 2. Prevalence of symptomatic and asymptomatic CAD

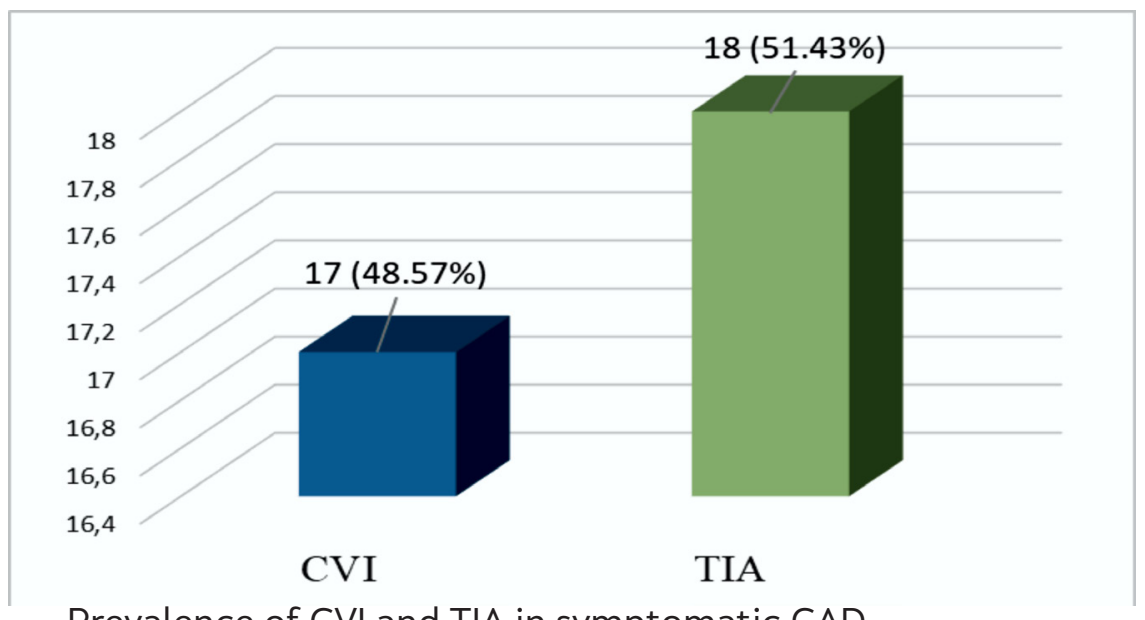

Figure 3. $\quad$ Prevalence of CVI and TIA in symptomatic CAD

Regarding the degree of carotid artery mal findings, 16 subjects had stenosis stenosis (CAS) in the total number of $<50 \%, 29$ subjects had stenosis $50-69 \%$, subjects with MetS and CAD, there 23 subjects had stenosis 70-99\%, and 9 were no reported subjects with nor- subjects had occlusion (Table1).

\begin{tabular}{|c|c|}
\hline $\begin{array}{c}\text { Degree of carotid artery stenosis (CAS) } \\
\text { in the total number of subjects with } \\
\text { MetS and CAD }\end{array}$ & (n) Number of patients \\
\hline$<50 \%$ & 16 \\
\hline $50-69 \%$ & 29 \\
\hline $70-99 \%$ & 23 \\
\hline Occlusion & 9 \\
\hline
\end{tabular}

Table 1. Degree of carotid artery stenosis (CAS) in symptomatic CAD 


\section{Discussion}

Due to the rise in the prevalence of MetS as a worldwide phenomenon and the increase in morbidity and mortality from cardio- and cerebrovascular disease, numerous studies have been performed to establish the correlation between MetS and cardio- and cerebrovascular events. The results of these studies showed a clear and strong association between them. According to the study by Gorter et al., the prevalence of MetS was $41 \%$ in subjects with coronary heart disease, $43 \%$ with cerebrovascular diseases, and $58 \%$ in patients with peripheral arterial disease 5. Namely, the results of the study by Ninomiya $\mathrm{JK}$ et al. Has indicated a strong, consistent association of MetS with prevalence of myocardial infarction and stroke6. The association between generalized atherosclerosis and carotid atherosclerosis and its major influence on the occurrence of cerebrovascular events has also been confirmed and known. Symptomatic CAD implies the etiological association of CAD with TIA and CVI. This is especially important since more than $80 \%$ of all strokes are ischemic strokes and only $20 \%$ are intracerebral haemorrhage. Of all ischemic strokes, three-fourths occupy the anterior circulation, while one-quarter of the posterior cerebral circulation accounts for the rest of ischemic strokes7. Namely, about $20-25 \%$ of stroke patients have confirmed atherosclerosis of the large blood vessels in the neck that feed the brain, of which 85\% are with CAD as a cause. There is a particularly increased risk of stroke in atherosclerotic stenotic lesions in the extracranial internal carotid artery or carotid bifurcation8. Similar results were obtained in our study; the overall prevalence of CAD among MetS subjects in this study was $65.25 \%$, of which $29.66 \%$ had symptomatic CAD of which $48.57 \%$ had CVI, 51.43\% were with TIA, and the rest were asymptomatic.

The prevalence of CAD varies with age and considerably depends on race. For all races the most important factor in the development of CAD is the increasing age. This has been confirmed by several studies, including the Los Angeles County General Hospital study9 and the Caron B. Rockman et al. study10. The results obtained from numerous CAD prevalence studies depend on the criteria applied, the research tools used, and the population covered. Thus, the prevalence of a significant carotid artery stenosis (50\% ultrasound-diagnosed carotid stenosis) in the Framingham study was $9 \%$ in men and $7 \%$ in women11. The highest prevalence was reported in people with acute stroke (60\%), then $18 \%$ in people with heart disease and $11 \%$ in people at increased risk for atherosclerosis12. There are numerous studies on the prevalence of moderate carotid stenosis that showheterogeneousdata on adultand gender distribution. However, most of them show that the prevalence of moderate carotid stenosis is higher in men than in women and that the prevalence increases with age in both men and women13-16. In our study, similar results were found for the prevalence of CAD according to gender distribution that was higher in men than in women $(34.75 \%$ vs. $30.51 \%)$. Regarding the degree of stenosis in symptomatic CAD, no subjects with normal findings were registered, 16 subjects had stenosis $<50 \%, 29$ subjects had stenosis 50 $69 \%, 23$ subjects had stenosis 70-99\% , and 9 subjects had occlusion . 


\section{Conclusion}

The results obtained in this study have shown that asymptomatic CAD is dominant in patients with MetS, which further imposes the need for timely extracranial ultrasonographic evaluation of the carotid trunk. This would achieve both effective prevention and adequate treatment of CVI and TIA, thereby reducing morbidity and mortality from cerebrovascular events which has a great health and socioeconomic significance.

\section{References}

1. Grundy SM. Pre-diabetes, metabolic syndrome, and cardiovascular risk. J Am Coll Cardiol 2012;59(7):635 - 43.

2. Anderson PJ, Critchley JAJH, Chan JCN, et al. Factor analysis of the metabolicsyndrome: obesity vs insulin resistanceas the central abnormality. Int J Obes 2001;25:1782

3. Hall HA, Bassiouny HS. Pathophysiology of carotid atherosclerosis. In: Nicolaides A, Beach KW, Kyriacou E, Pattichis CS, editors. Ultrasound Carotid Bifurc Atheroscler. New York: Springer; 2012; 27-39

4. Albers GW, Caplan LR, Easton JD, Fayad PB, Mohr JP, Saver JL, Sherman DG, for the TIA Working Group. Transient ischemic attack: proposal for a new definition. N Engl J Med 2002; 347: 1713-1716.

5. Gorter Pm, OlijhoekJk, VanDer Graaf Y, Lgra A, Rabelink Tj, Visseren Fl. Smart Study Group. Prevalence of the metabolic syndrome in patients with coronary heart disease, cerebrovascular disease, peripheral arterial disease or abdominal aortic aneu-rysm. Atherosclerosis 2004; 173: 363-9

6. Ninomiya JK, L'Italien G, Criqui MH, Whyte JL, Gamst A, Chen RS. Association of the metabolic syndrome with history of myocardial infarction and stroke in the Third National Health and Nutrition Examination Survey. Circulation 2004; 109: 42-46

7. Clou GC, Marku HS. Diagnosis and management of vertebral artery stenosis. QJM 2003;96:27-54.

8. Guidelines for Prevention of stroke in Patients with Ischemic Stroke or TIA. A Statement for Healthcare Professionals From the American Heart Association/American Stroke Association Council on Stroke. Circulation 2006;113:409 - 449

9. Wang MY, Mimran R, MohitA, Lavine SD, Giannotta S. Carotid stenosis in a multiethnic population. J Stroke Cerebrovasc Dis 2000;9: 64 - 9.

10. Rockman CB, Hoang $\mathrm{H}$, Guo Y, Maldonado TS, Jacobowitz GR, Talishinskiy T, et al. The prevalence of carotid artery stenosis varies significantly by race. J Vasc Surg 2013;2(57): 327 - 337.

11. Fine - Edelstein JS, Wolf PA, O'Leary $\mathrm{DH}$, et al. Precursors of extracranial carotid atherosclerosis in the Framingham Study. Neurology 1994;44:1046-1050.

12. Rockman CB, Jacobowitz GR, Gagne PJ, et al. Focused screening for occult carotid artery disease: patients with known heart disease are at high risk. J Vasc Surg 2004;39:44-51.

13. O‘Leary DH, Polak JF, Kronmal RA, Kittner SJ, Bond MG, Wolfson SK Jr, Bommer W, Price TR, Gardin JM, Savage PJ. Distribution and correlates of sonographically detected carotid artery disease in the Cardiovascular Health Study: the CHS Collaborative Research Group. Stroke 1992; 23: 1752-1760.

14. Sutton - Tyrrell K, Alcorn HG, Wolfson SK Jr, Kelsey SF, Kuller LH. Predictors of carotid stenosis in older adults with and without isolated systolic hypertension. Stroke 1993; 24: 355-361. 
15. Willeit J, Kiechl S. Prevalence and risk factors of asymptomatic extracranial carotid artery atherosclerosis: a population based study. Arterioscler Thromb 1993; 13: 661-668.
16. Fabris F, Zanocchi M, Bo M, Fonte G, Poli L, Bergoglio I, Ferrario E, Pernigotti L. Carotid plaque, aging, and risk factors: a study of 457 subjects. Stroke 1994; 25(6):1133-40. 